\title{
CHEMICAL, CLINICAL, AND IMMUNOLOGICAL STUDIES ON •THE PRODUCTS OF HUMAN PLASMA FRACTIONATION.

\author{
XVII. A NOTE ON THE ABSORPTION RATES \\ OF FIBRIN FILMS IN TISSUE 1,2
}

\author{
By PETER R. MORRISON AND MARCUS SINGER \\ (From the Departments of Physical Chemistry and Anatomy, Harvard Medical School, Boston)
}

(Received for publication February 17, 1944)

The most effective surgical use of fibrin film (1) or foam (2) demands some knowledge of their rates of absorption in the body.

Fundamental observations on the histological sequences involved in the course of absorption of fibrinogen plastics (1) implanted in tissue have been made by Bailey, Ford, and Hawn (3).

The present study was undertaken to measure the rates of absorption of various types of fibrin films, so that it might be possible to adjust the persistence of film in the body to meet specific requirements.

\section{MATERIALS AND METHODS}

The fibrin film used in these experiments was that described in the preceding paper (1), prepared from human fibrinogen $(4,5)$. It was subjected to varying degrees of modifying treatment before implantation. Squares of film $(1 \mathrm{~cm} . \times 1 \mathrm{~cm}$.) were then implanted subcutaneously and intermuscularly in rabbits and held in place by silk sutures. In order to determine the initial fibrin content of the implanted specimens, similar pieces of film were soaked in distilled water to free them of water-soluble substances, dried at $110^{\circ} \mathrm{C}$., and weighed to $0.3 \mathrm{mgm}$. This method was reproducible within 5 per cent. Three different weights of film were employed, with 4,9 , and $11 \mathrm{mgm}$. fibrin per sq.cm. The final fibrin content of the films was determined after different periods of implantation by submitting the remains of the films to the soaking, drying, and weighing procedure described above. In cases where encapsulation occurred, the weight of the capsule was measured separately after soaking and drying. Whereas the film may be easily recovered after brief periods of implantation, it becomes increasingly difficult to identify as absorption proceeds, owing to fragmentation and possible

\footnotetext{
1 This work has been carried out under contract, recommended by the Committee on Medical Research, between the Office of Scientific Research and Development and Harvard University.

2 This paper is Number 23 in the series "Studies on Plasma Proteins" from the Harvard Medical School, Boston, Massachusetts, on products developed by the Department of Physical Chemistry from blood collected by the American Red Cross.
}

invasion of fibrous tissue. Hence, the results for the long periods of implantation must be considered as less reliable than those obtained for short periods.

\section{RESULTS}

The results demonstrated that a considerable range of persistence times may be obtained, depending on the extent of modifying treatment of the films. Untreated film was absorbed most rapidly; the rate of absorption decreased with an increasing degree of treatment.

Untreated films. Complete absorption of all the untreated films $(4,9$, and $11 \mathrm{mgm}$. fibrin per sq.cm.) occurred in less than 9 days. Even at the earliest time of examination (5 days), the film was very weak and could not be removed in a single piece. The rate of absorption of each film was roughly constant over the entire period. It varied from $0.85 \mathrm{mgm}$. per sq.cm. per day for the $4 \mathrm{mgm}$. per sq.cm. film to $1.40 \mathrm{mgm}$. per sq.cm. per day for the $11 \mathrm{mgm}$. per sq.cm. film,

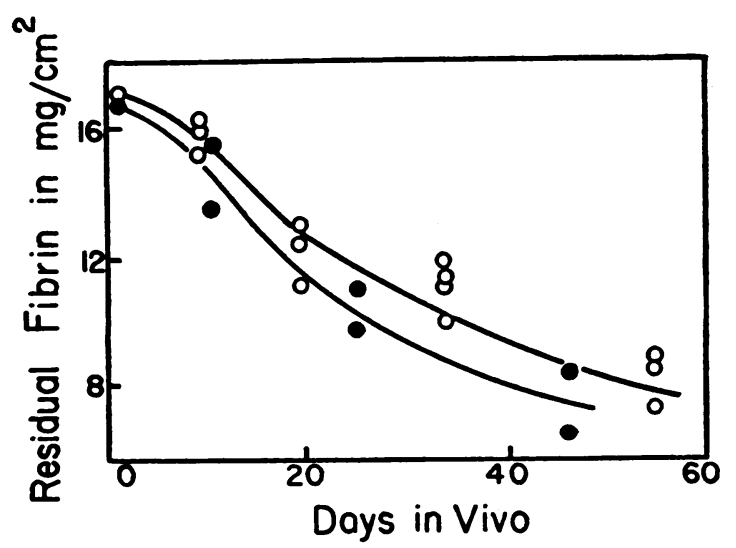

Fig. 1. Course of Absorption of Treated Films: Residual Fibrin Plotted Against Time of ImplanTATION IN DAYS

Initial weight $17 \mathrm{mgm}$. per sq. $\mathrm{cm}$. per day. 
the rate thus being not quite proportional to the original thickness.

Treated films. The rate of absorption of the films with the greatest modifying treatment was much slower than the above and fell off progressively with time (Figure 1). These films disappeared initially at the rate of 0.25 to 0.35 mgm. per day; by 40 days, however, the rate had fallen to 0.12 to $0.14 \mathrm{mgm}$. per day. Total

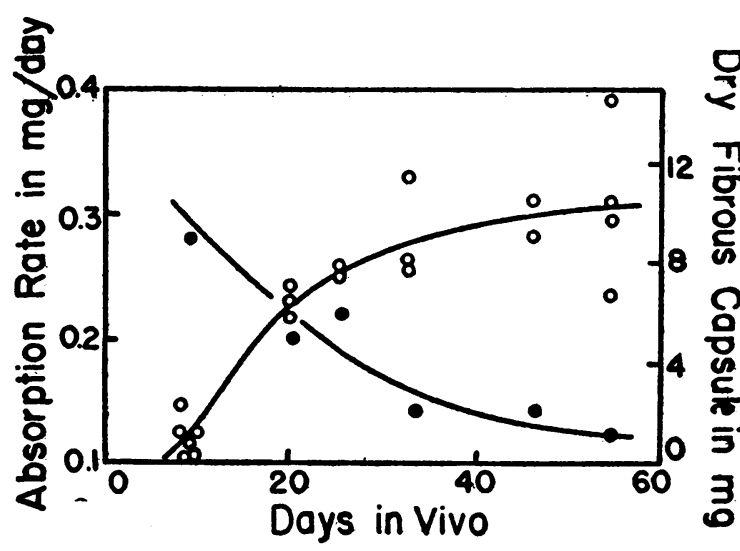

Fig. 2. Absorption of Treated Films and Defvelopment of Capsule

Rate of absorption of films in mgm. per sq. $\mathrm{cm}$. per day - a. Dry weight of capsule in mgm.- $O$.

absorption of the film was not complete even in the one animal allowed to live for $\mathbf{8 1}$ days after implantation. The fall in absorption rate was associated with the development of a capsule, which was easily separable from the surrounding



Fig. 3. Course of Absorption of Filys with Sligit Treatment: Regidual Fibrin Plotted Against Tone of Impeantation

Initial weights of $4(\Delta), 9(0)$, and $11(\square)$ mgm. per sq. cm. loose connective tissue and completely enclosed the film (Figure 2). The latter, in turn, lay free inside the capsule, and, unlike the untreated film, could usually be removed in a single piece, although its tensile strength had dropped considerably. It is possible that the decrease in rate of absorption was due merely to the formation of the capsule and not to any difference in the absorption process.

Intermediate degrees of modifying treatment produced films with intermediate absorption rates. The absorption curves for slightly treated films were similar to those of untreated film (Figure 3).

\section{COMMENT}

The range of absorption rates (from 0.2 to 1.4 mgm. per sq.cm. per day) shown by the various types of film, in combination with different weights of film available, offer a wide latitude in choosing a film for any specific purpose.

The fact that the absorption rate, when expressed in mgm. per sq.cm. per day, is roughly proportional to the initial film weight for untreated films and also for those of slight degrees of treatment, means that the absorption rates, expressed as per cent of original weight, and the total persistence times, are essentially independent of film weight. This suggests that the absorptive process involves the entire film simultaneously and is in all probability not localized at the surface.

Although the extent to which the results of animal experiments with a heterologous protein can be applied to man is never certain, histological and gross observations on clinical material (6) suggest that, in general, absorption rates and types of reaction to the films are qualitatively similar, though quantitative differences may well obtain between different species, and between different tissues of a given species.

\section{SUMMARY}

The rates of absorption of fibrin films in tissue have been measured.

Persistence times, ranging from less than 5 days for untreated fibrin film to more than $\mathbf{8 0}$ days for fully treated films, have been observed. For films of extended persistence time, an encap- 
sulation occurs between 10 and 30 days after implantation. The choice of material for surgical use should be guided by the persistence time desired for each specific application.

\section{BIBLIOGRAPHY}

1. Ferry, J. D., and Morrison, P. R., Chemical, clinical, and immunological studies on the products of human plasma fractionation. XVI. Fibrin clots, fibrin films, and fibrinogen plastics. J. Clin. Invest., $1944,23,566$.

2. Bering, E. A., Jr., Chemical, clinical, and immunological studies on the products of human plasma fractionation. XX. The development of fibrin foam as a hemostatic agent and for use in conjunction with human thrombin. J. Clin. Invest., 1944, 23, 586.

3. Bailey, O. T., Ford, R. M., and Hawn, C. v. Z., The behavior of a series of fibrinogen plastics in animal tissues with a note on the effect of plasticizing agents on fibrinogen-thrombin film. A report to the Proctor Fund, Harvard University, September 1, 1942.

4. Cohn, E. J., Oncley, J. L., Strong, L. E., Hughes, W. L., Jr., and Armstrong, S. H., Jr., Chemical, clinical, and immunological studies on the products of human plasma fractionation. I. The characterization of the protein fractions of human plasma. J. Clin. Invest., 1944, 23, 417.

5. Edsall, J. T., Ferry, R. M., and Armstrong, S. H., Jr., Chemical, clinical, and immunological studies on the products of human plasma fractionation. XV. The proteins concerned in the blood coagulation mechanism. J. Clin. Invest., 1944, 23, 557.

6. Bailey, O. T., and Ingraham, F. D., Chemical, clinical, and immunological studies on the products of human plasma fractionation. XXII. Fibrin films in neurosurgery, with special reference to their use in the repair of dural defects and in the prevention of meningocerebral adhesions. J. Clin. Invest., 1944, 23, 597. 